\title{
Shortgrass range vegetation and steer growth response to intensive-early stocking
}

\author{
KENNETH C. OLSON, JOHN R. BRETHOUR, AND JOHN L. LAUNCHBAUGH
}

\begin{abstract}
Authors are former range scientist, animal scientist, and range scientist emeritus, Fort Hays Branch Experiment Station, Kansas State Univ., 1232 240th Avenue, Hays 67601. Olson is currently range livestock nutritionist, ADVS Dept., Utah State Univ., Logan 84322-4815.
\end{abstract}

\begin{abstract}
A 9-year grazing trial was conducted to compare shortgrass vegetation and steer responses under intensive-early stocking (IES) at 2 stocking rates to season-long stocking (SLS). The stocking rates were (1) equal to SLS, with twice as many steers used for the first half of the SLS grazing season (2X-IES), and (2) greater than SLS, with 3 times as many steers used for the same period (3XIES). The hypothesis tested was that SLS and 2X-IES would be similar and sustainable in terms of productivity and vegetation composition, whereas $3 X$-IES would be different and not sustainable. The 3 treatments were assigned to 6 pastures in a randomizedcomplete block. Grazing was initiated on or near 1 May each year and continued until about $15 \mathrm{July}$ for IES and about 1 October for SLS. Steers were weighted at initiation of grazing and in mid-July, and SLS steers were weighed in October. Vegetation data were collected in July and October in each pasture from 10 randomly located plots. Species composition of grasses was estimated, and grasses and forbs were clipped separately to determine biomass availability. Steer total gain and average daily gain (ADG) under SLS and $2 X$-IES were equal $(P>0.10)$ during the early season, but 3X-IES gain and ADG were less $(P<0.05)$. Total-season gain was greater under SLS $(P<0.05)$ than either IES treatment, but totalseason ADG was equal to that under $2 X$-IES. Steer production per ha was equal under SLS and 2X-IES, but greater under 3X-IES $(P<0.05)$. Western wheatgrass [Pascopyrum smithii(Rydb.) Löve] and buffalograss (Buchloe dactyloides (Nutt.) Engelm.) composition did not change over time under SLS and 2X-IES, but decreased and increased, respectively, under 3X-IES $(P<0.05)$. Blue grama (Bouteloua gracilis (HBK.) Lag. ex Steud.) and annual grasses displayed initial composition differences $(P<0.10)$ among grazing treatments, but not differential composition shifts over time $(P>0.10)$. Grass and total biomass availability were reduced $(P<0.10)$ over time by $3 X-I E S$. The hypothesis was supported: SLS and 2X-IES were equal in terms of both livestock performance and vegetation responses, but livestock performance and biomass availability were reduced and vegetation composition changed under $3 X$-IES. Thus, $3 X$-IES was not sustainable. While SLS and $2 X$-IES appear biologically equal, using them simultaneously on separate land areas may reduce market variability risk by marketing twice per year.
\end{abstract}

Key Words: grazing system, native range, beef cattle, stockers, weight gain

Intensive-early stocking (IES) is a grazing management practice based on seasonal suitability and is designed to improve the efficiency of converting vegetation to livestock products while sustaining the natural resource. Under IES, stocker cattle are placed on rangeland in the spring at double the number recommended for

\footnotetext{
Contribution 92-250-J from the Kansas Agricultural Experiment Station.

The authors thank $H$. Jansonius for technical assistance.

Manuscript accepted 7 June 1992.
}

season-long stocking (SLS), but are removed at the midpoint of the SLS grazing season. The result is double stocking density (animal units/ha) during the grazing season, but a stocking rate (animal unit-months (AUM)/ha) equivalent to SLS. The purposes are to concentrate grazing during the period of highest nutritional quality of the forage, thus increasing livestock production, and to allow a late-season rest so that desirable species enter the dormant season in high vigor.

On tallgrass prairie in eastern Kansas (Smith and Owensby 1978) and eastern Oklahoma (McCollum et al. 1990) and on shortgrass prairie in eastern Colorado (Klipple 1964), individual animal performance under IES was equal to or slightly greater than under SLS during the early grazing season, despite the doubled stocking density. In all 3 studies, gain under IES was $65-67 \%$ of that by SLS cattle for the entire grazing season, resulting in a $19-34 \%$ increase in gain per unit of land. On tallgrass prairie, IES maintained or improved desirable species composition and productivity (Smith and Owensby 1978, McCollum et al. 1990). However, on shortgrass prairie, IES changed species composition and reduced biomass production (Klipple 1964). Owensby et al. (1988) subsequently compared IES at $2,2.5$, and 3 times (2X-, 2.5X-, and $3 X$-IES) the number of cattle recommended for SLS on tallgrass prairie. Steer gains were equal, resulting in increased gain per land unit as stocking rate increased. The late-season rest allowed tallgrass prairie vegetation to sustain productivity at all stocking rates tested.

The objective of this study was to compare responses of shortgrass vegetation and stocker cattle growth under IES at 2 stocking rates (2X-IES and 3X-IES) to SLS. Our hypothesis was that 2X-IES would be equal to SLS and sustainable, in terms of vegetation composition and steer production, but that $3 X$-IES would not be sustainable or as productive on this vegetation type.

\section{Materials and Methods}

\section{Study Site}

The study was conducted on the Fort Hays Branch Experiment Station located near Hays, in west-central Kansas. The climate is semiarid with a long-term mean annual precipitation of $571 \mathrm{~mm}$, of which $77 \%$ occurs during A pril through September. Mean precipitation during the study was $540 \mathrm{~mm}$, with 5 years above and 4 years below the long-term mean (Fig. 1).

The study area was composed primarily of a loamy upland range site with small inclusions of limy upland and loamy lowland. These inclusions were primarily the slopes and bottoms of small drainages, respectively. Soils were Typic Argiustolls on loamy upland, Typic Haplustolls on limy upland, and Cumulic Haplustolls on loamy lowland range sites. The vegetation was typical of shortgrass plains. Dominant species were western wheatgrass [Pascopyrum smithii (Rydb.) Löve], buffalograss (Buchloe dactyloides (Nutt.) Engelm.), and blue grama (Bouteloua gracilis (HBK.) Lag. ex Steud.). Subdominant species were Japanese brome (Bromus 

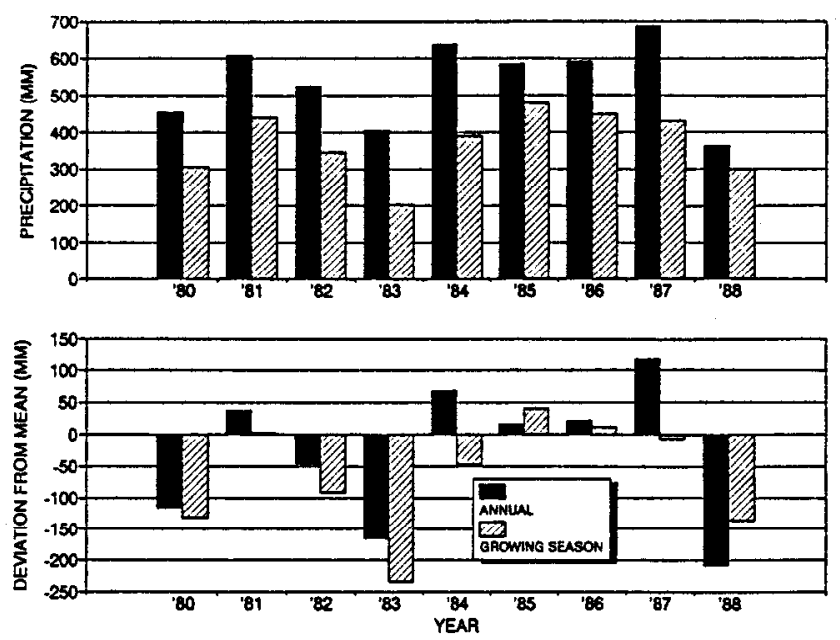

Fig. 1. Total annual and growing season precipitation ( $\mathrm{mm}$ ) and deviation of each from the long-term means of 570 and $437 \mathrm{~mm}$, respectively.

japonicus Thunb.) and western ragweed (Ambrosia psilostachya DC.). Numerous other grass and forb species occurred in minor amounts (Launchbaugh 1967).

\section{Grazing Treatments}

The study was initiated in 1980 and continued through 1988. Three grazing treatments were included. The control was SLS at 1.4 ha per steer for a 5-month grazing season (1 May to 1 October). Previous long-term research indicated that this stocking rate was sustainable on this site (Launchbaugh 1957). The other 2 treatments were IES at 2 stocking densities, 0.7 ha per steer for $2 X$-IES and 0.5 ha per steer for $3 X$-IES, for a 2.5 -month grazing season (1 May to 15 July). Double-stocked IES (2X-IES) yielded an equal stocking rate to SLS ( 0.4 ha per AUM) and 3 X-IES yielded a stocking rate of 0.3 ha per AUM. At initiation of the trial, treatments were assigned to 6 pastures in a randomized-completeblock. The blocking factor was the area of limy upland and loamy lowland range site in the pastures. Each treatment remained on the same pastures throughout the study. Pastures were 12.5 ha (block 1) or 14.6 ha (block 2), so steer numbers per pasture were 9 or 10,18 or 20 , and 27 or 31 for blocks 1 or 2 of SLS, 2X-IES, and 3X-IES, respectively. Actual dates that grazing was initiated and terminated each year are shown in Table 1 .

\section{Experimental Livestock}

Yearling steers (12 to 14 months of age) of British breeding

Table 1. Dates of initiation and termination of grazing, number of days of grazing, and initial weight of steers used each year for SLS and IES treatments.

\begin{tabular}{|c|c|c|c|c|c|c|}
\hline \multirow[b]{2}{*}{ Year } & \multirow[b]{2}{*}{ Initiation } & \multicolumn{2}{|c|}{ Termination } & \multicolumn{2}{|c|}{ Grazing period } & \multirow[b]{2}{*}{$\mathbf{W t}$} \\
\hline & & IES & SLS & IES & SLS & \\
\hline & & & \multicolumn{4}{|c|}{ - - - (Days) - - - } \\
\hline 1980 & $6 \mathrm{May}$ & $18 \mathrm{Jul}$ & 1 Oct & 73 & 148 & 304 \\
\hline 1981 & $15 \mathrm{Apr}$ & $1 \mathrm{Jul}$ & $17 \mathrm{Sep}$ & 77 & 155 & 259 \\
\hline 1982 & 4 May & $20 \mathrm{Jul}$ & $4 \mathrm{Oct}$ & 77 & 153 & 272 \\
\hline 1983 & 11 May & $23 \mathrm{Jul}$ & 3 Oct & 73 & 145 & 278 \\
\hline 1984 & 4 May & $16 \mathrm{Jul}$ & 3 Oct & 73 & 152 & 1 \\
\hline 1985 & 2 May & $15 \mathrm{Jul}$ & 1 Oct & 74 & 152 & \\
\hline 1986 & 1 May & $14 \mathrm{Jul}$ & $29 \mathrm{Sep}$ & 74 & 151 & \\
\hline 1987 & $30 \mathrm{Apr}$ & $16 \mathrm{Jul}$ & $2 \mathrm{Oct}$ & 77 & 155 & 308 \\
\hline 1988 & $28 \mathrm{Apr}$ & 29 Jun & 7 Sep & 62 & 132 & 342 \\
\hline
\end{tabular}

ILivestock weights for 1984-1986 were not used.
(Hereford, Angus, or Hereford $\times$ Angus) with a mean initial weight of $294 \mathrm{~kg}$ (Table 1) were used in most years of the study. The exceptions to this were 1985 and 1986, when a study comparing steers with different frame scores (derived from different breed combinations) was superimposed on this experiment. Additionally, during 1984 through 1986 , a supplementation experiment was superimposed on this study by feeding $1.8 \mathrm{~kg}$ of sorghum grain daily to all steers on 1 replicate of each treatment and not supplementing the other replicate. This eliminated the opportunity to statistically analyze the livestock gain data for those 3 years, and they were deleted from the data set. Therefore, livestock response data from 1980 through 1983 and 1987 through 1988 were analyzed. Steers had continuous ad libitum access to salt throughout the grazing season. All steers were implanted once with a growth promotant (either Ralgro ${ }^{\circledR}$. Compudose ${ }^{\circledR}$, or Synovex-S $\odot$ ) at initiation of grazing each year.

\section{Data Collection}

All steers were weighed at initiation of grazing and in mid-July at termination of IES grazing; SLS steers were weighed at termination of their grazing season. Weights were recorded in the morning after a 12- to 15-hour stand without feed or water.

Vegetation data were collected twice per year in all pastures, at the termination of IES grazing in mid-July, and at the termination of SLS grazing in early October, except in 1981 when data were not collected in October. Ten $0.3 \times 0.6 \mathrm{~m}\left(0.18 \mathrm{~m}^{2}\right)$ plots were randomly located in each pasture at each collection time. Forbs were clipped from the plot, composition of grasses and sedges (Carex spp. L.) was visually estimated, and then they were clipped and bagged separately from the forbs. Grass and sedge composition was estimated for 6 groups: western wheatgrass, buffalograss, blue grama, annual grasses, standing dead, and miscellaneous (all other grass species and sedges). Annual grasses was mostly Japanese brome. Standing dead included all grass and sedge species; all other categories included only current year's growth. Visual estimation was done separately by 2 people and results were averaged for each plot. Clipped samples were dried at $100^{\circ} \mathrm{C}$ to a constant weight.

\section{Data Analysis}

All data were analyzed using the General Linear Models procedure of the Statistical Analysis System (SAS Institute, Cary, N.C.). Least squares procedures were used to estimate means. Following significant $F$ tests, means were separated using single-degree-offreedom contrasts. All tests were considered significant at $P \leq 0.10$.

Steer response, including total gain per head, average daily gain (ADG) per head, gain per ha, and final weight were analyzed using analysis of covariance. Main effects were grazing treatment, year, and the treatment $\times$ year interaction in a repeated measures treatment structure. Initial weight was used as a covariate. This model was run once using the SLS data for the IES grazing season, then rerun after substituting the SLS data for the entire SLS grazing season. We felt that data for both time seasons of SLS should not be incorporated into the same model with IES, because both SLS time period responses were derived from the same experimental units and could not be considered independent and random samples. A separate model was used to compare gain per head and ADG between the first and last halves of the SLS grazing season. Mean effects in this model were portion of the grazing season, year, and season $X$ year in a repeated measures treatment structure.

Vegetation data from all years of the study were analyzed. It was assumed that supplementation in some pastures did not influence forage utilization because Vanzant et al. (1990) reported that supplementation of grain sorghum at $1.8 \mathrm{~kg}$ did not reduce intake of immature forage. Dependent variables were percent composition 
of each of the 7 species groups (western wheatgrass, buffalograss, blue grama, annual grasses, standing dead, miscellaneous grasses, and forbs), and yield of grasses, forbs, and total herbage. Because our interest in species composition change was among years as the study progressed, and not in composition changes within years, the composition data were combined within years by using the mean of the July and October data sets for each pasture. Within-year effects on the biomass responses were of interest because of differential stocking densities and grazing seasons, so these data were not composited across July and October. The vegetation data were analyzed using analysis of covariance to evaluate heterogeneity of slopes (Freund and Littell 1981). This analysis allowed the evaluation of our 2 objectives: comparison of treatments and detection of changes through time that would indicate sustainability. For the species composition data, the model contained grazing treatment as a class effect, year as a covariate, and the treatment $X$ year interaction. A significant treatment $X$ year interaction indicated that the regression slopes among grazing treatments were different. These were interpreted as differential effects of grazing treatments over time. A significant treatment effect indicated different intercepts for the individual treatment regressions that were interpreted as differences in initial composition. For the biomass categories, a similar model was used, except month (July and October) and its 2-and 3-way interactions with treatment and year were added in a repeated measures treatment structure.

\section{Results and Discussion}

\section{Steer Response}

Total gain, ADG, final weight, and production per ha all responded $(P<0.05)$ to grazing treatments (Table 2$)$. This was true for SLS responses during both the early season and the total

Table 2. Influence of grazing treatments on steer total gain, ADG, final weight, and production per hal.

\begin{tabular}{|c|c|c|c|c|}
\hline \multirow[b]{3}{*}{ Variable } & \multicolumn{4}{|c|}{ Grazing treatment ${ }^{2}$} \\
\hline & \multicolumn{2}{|c|}{ SLS } & \multirow[b]{2}{*}{ 2X-IES } & \multirow[b]{2}{*}{ 3X-IES } \\
\hline & early season & total season & & \\
\hline $\begin{array}{l}\text { Gain/hd (kg) } \\
\text { ADG (kg) } \\
\text { Final Wt (kg) } \\
\text { Gain/ha (kg) }\end{array}$ & $\begin{array}{c}52.5 \pm 1.2^{\mathrm{a}} \\
0.72 \pm .01^{\mathrm{a}} \\
346.3 \pm 1.3^{\mathrm{a}} \\
38.1 \pm 1.8^{\mathrm{a}}\end{array}$ & $\begin{array}{r}92.5 \pm 1.3^{x} \\
0.63 \pm 0.1^{x} \\
386.3 \pm 1.4^{x} \\
66.7 \pm 1.9^{x}\end{array}$ & $\begin{array}{r}49.8 \pm 1.0^{\text {ay }} \\
0.68 \pm .01^{\text {ax }} \\
343.7 \pm 1.1^{\text {ay }} \\
71.5 \pm 1.5^{\text {bx }}\end{array}$ & $\begin{array}{r}40.3 \pm 1.0^{\mathrm{bz}} \\
0.55 \pm .01^{\mathrm{by}} \\
334.4 \pm 1.1^{\mathrm{bz}} \\
81.7 \pm 1.5^{\mathrm{cy}}\end{array}$ \\
\hline
\end{tabular}

'Least squares means \pm standard error $(n=2)$.

${ }^{2}$ SLS = Season-long stocking, data reported for SLS response during IES grazing season and season-long: $2 \mathrm{X}$-IES = intensive-early stocking with twice as many steers as SLS; 3X-IES = intensive-early stocking with 3 times as many steers as SLS.

SL, b, M Mean comparison of early-season SLS, 2X-IES, and 3X-IES. Unlike superscripts within rows signify difference among means $(P \leq 0.10)$.

within rows signify difference among means $(P \leq 0.10)$.
$x_{x, y}$ Mean comparison of total-season SLS, $2 X-I E S$, and $3 X-I E S$. Unlike superscripts $x, y, z$ Mean comparison of total-season SLS, $2 X-I E S$, and
within rows signify differences among means $(P \leq 0.10)$

season. Mean separations indicated that early-season gain, ADG, and final weight were all equal under SLS to those under $2 X$-IES $(P>0.10)$, but were reduced under $3 \mathrm{X}$-IES $(P<0.10$, Table 2$)$. Additionally, total-season ADG under SLS was similar to ADG under 2X-IES $(P>0.10)$, resulting in greater total gain and final weight for SLS $(P<0.10)$. Steer gain per ha was equal for totalseason SLS and 2X-IES $(P>0.10)$ and greater for 3X-IES $(P<0.10)$. The increased stocking rate under $3 \mathrm{X}-\mathrm{IES}$ resulted in greater production per ha, despite reduced performance per individual. Production per ha was less during early-season SLS than for all other grazing treatments $(P<0.10)$.

Steer performance variables did not display $(P>0.10)$ treatment $X$ year interactions for early or total season, or year effects for total-season responses $(P>0.10)$, but did respond to years $(P<0.10)$ in the early season. Years with the poorest and the best early- season steer performance ( 1980 and 1987 , respectively) were different $(P<0.10)$, with all other years intermediate and equal to the extreme years (Table 3). Differences in precipitation (Fig. 1) or genetic capability of the steers among years probably contributed to this variation.

Table 3. Gain per head and ADG under SLS partitioned into the early and late halves of the graxing season for each year and early gain as a percent of total gain.

\begin{tabular}{|c|c|c|c|c|c|}
\hline \multirow[b]{2}{*}{ Year } & \multicolumn{2}{|c|}{ Gain' } & & \multicolumn{2}{|c|}{$\mathrm{ADG}^{2}$} \\
\hline & early & late & & early & late \\
\hline & \multicolumn{2}{|c|}{$\cdots \cdots(\mathbf{k g})-\cdots$} & $\%^{3}$ & \multicolumn{2}{|c|}{$\ldots \ldots-(\mathrm{kg})-\ldots$} \\
\hline 1980 & $35.6^{\mathrm{a}}$ & $51.4^{\mathrm{a}}$ & 41 & $0.48^{\mathrm{a}}$ & $0.68^{a}$ \\
\hline 1981 & $55.8^{a}$ & $52.4^{\mathrm{a}}$ & 52 & $0.72^{\mathrm{a}}$ & $0.67^{a}$ \\
\hline 1982 & $58.8^{\mathrm{a}}$ & $36.6^{\mathrm{b}}$ & 62 & $0.76^{a}$ & $0.48^{b}$ \\
\hline 1983 & $49.2^{\mathrm{n}}$ & $34.1^{\mathrm{a}}$ & 59 & $0.67^{\mathrm{a}}$ & $0.47^{n}$ \\
\hline 1987 & $65.2^{\mathrm{a}}$ & $25.4^{b}$ & 72 & $0.86^{\mathrm{a}}$ & $0.32^{b}$ \\
\hline 1988 & $45.3^{a}$ & $33.4^{a}$ & 58 & $0.74^{a}$ & $0.47^{\mathrm{b}}$ \\
\hline
\end{tabular}

iStandard error $=7.8(\mathrm{n}=2)$.

2Standard error $=0.11(n=2)$

${ }^{3}$ The percentage of total SLS gain achieved during the first half of the grazing season. ${ }_{a},{ }^{6}$ Unlike letters within each yearly pair indicate early- and late- season gain or ADG were different $(P \leq 0.10)$.

Season $X$ year interacted $(P<0.10)$ in the model comparing early- to late-season total gain and ADG under SLS (Table 3). The mean percentage of total-season gain achieved in early season was $57 \%$ and ranged from 41 to $72 \%$. Early-season gain per head and ADG were greater than late-season responses in only 2 and 3 , respectively, of the 6 years $(P<0.10)$, with the remaining years displaying equal responses among seasons $(P>0.10)$.

The small and inconsistent differences between early- and lateseason gains under SLS was unexpected (Table 3). Previous IES studies (Klipple 1964, Smith and Owensby 1978, and McCollum et al. 1990) consistently demonstrated that $65 \%$ of total gain occurred in early season, with little variation among years. Apparently, the decline in forage quality as the growing season progresses is not as rapid or consistent among years on shortgrass prairie as was demonstrated in the studies on tallgrass prairie (Smith and Owensby 1978, McCollum et al. 1990). Although Klipple's (1964) study was conducted on shortgrass prairie, later dates of livestock removal (about 10 August and 10 November for IES and SLS, respectively) probably reduced late-season steer growth compared to this study. Because of the small difference in seasonal gain in this study, 2X-IES did not provide the gain efficiency necessary to increase production per ha over SLS (Table 2), as occurred in the studies cited above. Additionally, steer gain was reduced under $3 X$-IES, in contrast to Owensby et al. (1988), wherein gain was equal at $2 \mathrm{X}$-, 2.5X- and 3X-IES. Economic analyses (McCollum et al. 1990) suggested that steers need to gain at least $60 \%$ of SLS potential gain during early-season grazing for IES to be economically advantageous. This break-even target was tangibly exceeded in only 1 year, was nearly equalled in 3 years, and the percentage was substantially less in 2 years (Table 3 ).

\section{Vegetation Composition Reponse}

Western wheatgrass and buffalograss displayed grazing treatment $X$ year interactions $(P<0.05)$, but not grazing treatment effects $(P>0.10)$, indicating similar intercepts and different slopes (Fig. 2). In other words, composition was similar in the first year of the trial, but differential treatment responses occurred over time. For both species, slopes were not different from 0 for SLS and 2X-IES $(P>0.10)$, but western wheatgrass decreased $(P<0.001)$ and buffalograss increased $(P<0.0005)$ under $3 \mathrm{X}$-IES. For both species, the $3 X-I E S$ slope was different from the SLS and $2 X$-IES 

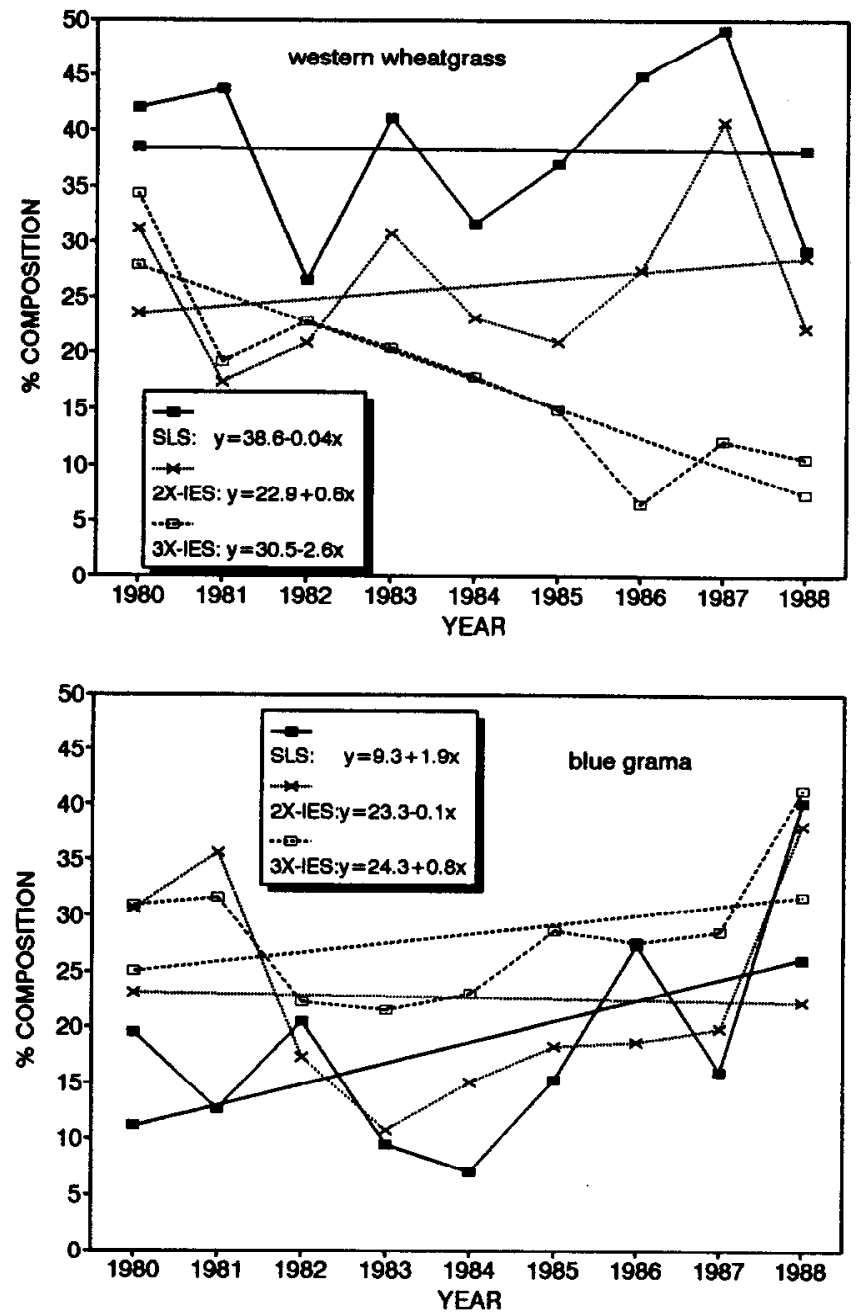
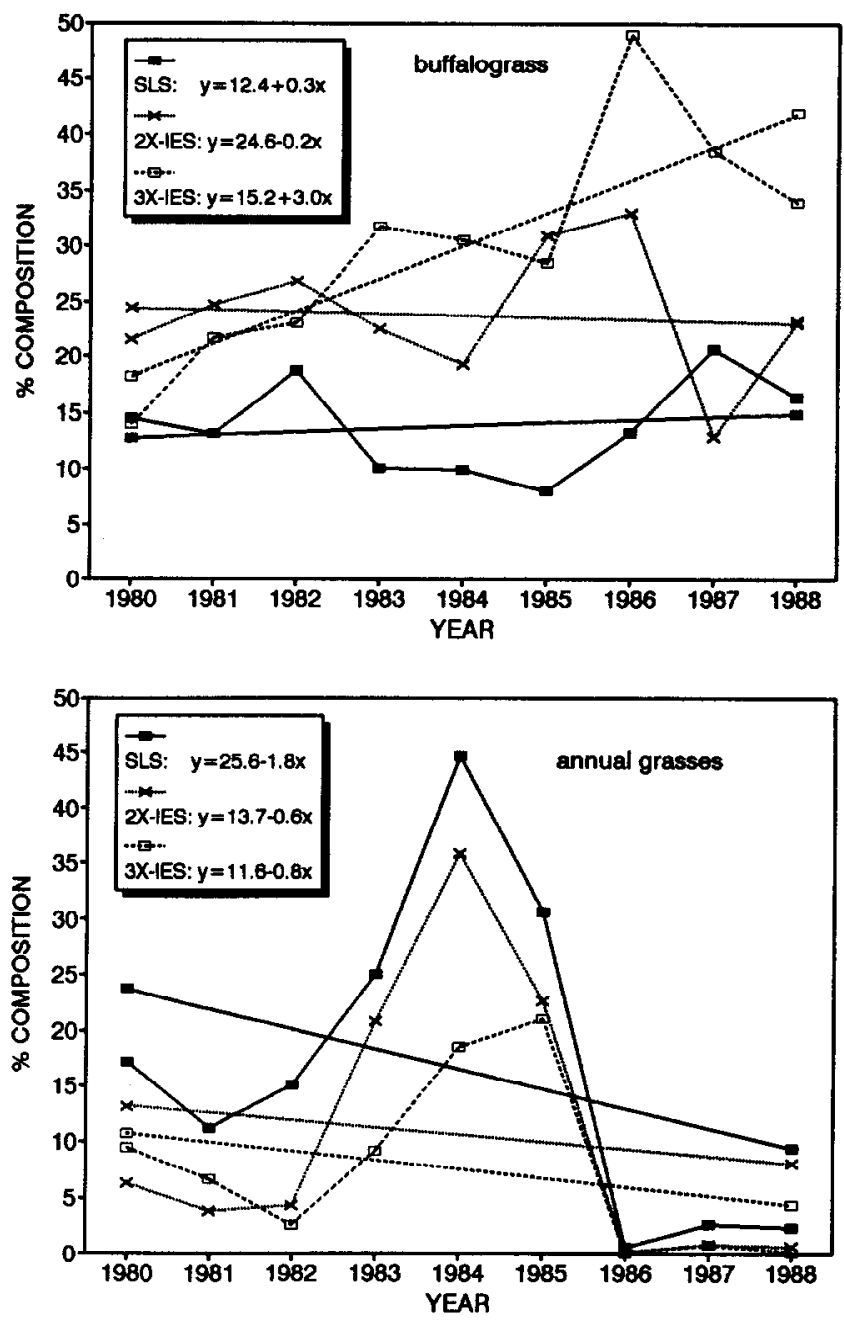

Fig. 2. Species or species group composition responses to season-long stocking (SLS), double-stocked intensive-early stocking (2X-IES), and triplestocked intensive-early stocking (3X-IES). Markers connected by crooked lines are the actual data. Similar markers connected by straight lines are the regressions through those data.

slopes $(P<0.05)$, whereas SLS and $2 X$-IES slopes were similar $(P>0.10)$.

Blue grama and the annual grasses group displayed grazing treatment responses $(P<0.10)$, but not treatment $\times$ year interactions $(P>0.10)$, indicating different intercepts and similar slopes among grazing treatments (Fig. 2). In other words, initial composition was different, probably because of previous grazing history, but differential changes in composition of these 2 components did not occur during the study. Both IES treatments had greater initial amounts of blue grama and lower initial amounts of annual grasses than SLS $(P<0.10)$, but were equal to each other $(P>0.10)$. Although IES may concentrate livestock grazing during the early season when Japanese brome is most nutritious and palatable, it does not appear to be a means of reducing its contribution to species composition.

The miscellaneous grasses group, standing dead, and forb composition did not respond $(P>0.10)$.

\section{Vegetation Biomass Response}

Grass and total biomass both exhibited treatment $\times$ year interactions $(P<0.10$, Fig. 3), but not grazing treatment effects $(P>0.10)$. Forb biomass did not display any responses $(P>0.10)$. Although the actual slope coefficients for grass and total biomass were almost identical for each grazing treatment regression, differences occurred in the estimate comparisons among biomass categories. Grass biomass slopes were not different from 0 for SLS and
2X-IES $(P>0.10)$, but grass biomass declined under 3X-IES $(P<0.05)$. The $2 X-I E S$ and $3 X-I E S$ slopes were different $(P<0.10)$, with the SLS slope being intermediate and equal to both IES slopes $(P>0.10)$. However, the SLS slope for total biomass responded differently. It declined over years $(P<0.10)$ like $3 X-I E S$, and only 2X-IES was not different from $0(P>0.10)$. In this case, the SLS and $3 X-I E S$ slopes were equal $(P>0.10)$ to each other and different from $2 X$-IES $(P<0.10)$.

Grass and total biomass also displayed month effects $(P<0.05)$, but month did not interact with grazing treatment or year $(P>0.10)$. Biomass in July [2458 $\pm 111 \mathrm{~kg} / \mathrm{ha}$ (mean $\pm \mathrm{SE}$ ) for grass and $2,637 \pm 113 \mathrm{~kg} /$ ha for total] was greater $(P<0.05)$ than biomass in October $(2,032 \pm 118 \mathrm{~kg} /$ ha for grass and $2,219 \pm 120 \mathrm{~kg} /$ ha for total) for both categories.

The data supported our hypotheses that vegetation responses under 2X-IES would be equal to those under SLS and plant communities would be sustainable under $2 X$-IES and SLS, but not under 3X-IES. The 3X-IES treatment caused a reduction over time in western wheatgrass (Fig. 2), the major cool-season grass species, and an increase in buffalograss, an important warm-season component. Shifts from cool- to warm-season grasses under repeated early-season use has been documented previously (Jameson 1991). Interestingly, blue grama did not display a similar response to buffalograss, even though it is a warm-season grass. The shift from western wheatgrass to buffalograss under $3 \mathrm{X}$-IES corresponded with reduced grass and total biomass (Fig. 3), indicating 

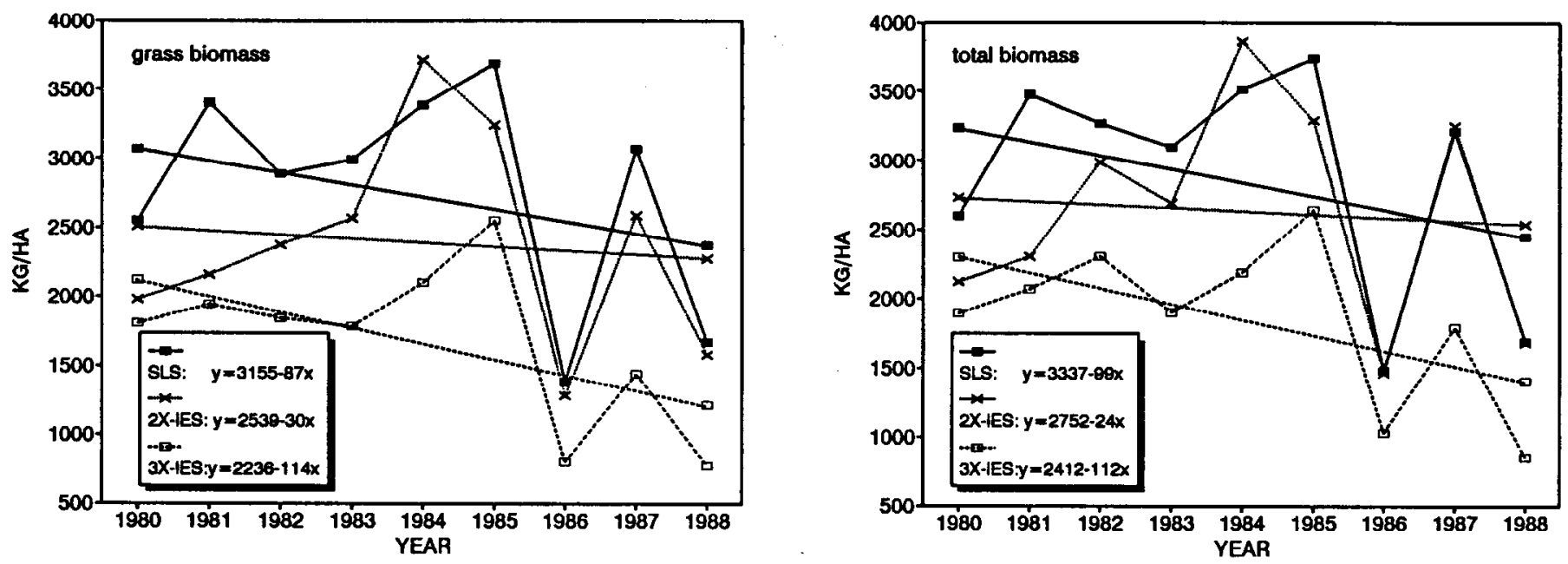

Fig. 3. Grass and total biomass responses to season-long stocking (SLS), double-stocked intensive-early stocking (2X-IES), and triple-stocked intensive-early stocking (3X-IES). Markers connected by crooked lines are the actual data. Similar markers connected by straight lines are the regressions through those data.

that buffalograss, a shortgrass, could not produce as much biomass as western wheatgrass, a midgrass. However, Klipple (1964) even found reduced total biomass at $2 \mathrm{X}$-IES, particularly for midgrasses (presumably mostly western wheatgrass).

The reduction in total biomass under SLS over time was disturbing. Examination of Figure 3 indicated that this response was primarily because of severely reduced biomass in 1986. About 32 ha of the study area was subjected to a wildfire on 17 February 1986. To maintain equal perturbation, the remainder of the study area was burned on 25 February 1986 . Winter wildfires reduce biomass production during the following growing season (Launchbaugh and Owensby 1978). The grass, forb, and total biomass responses were reanalyzed with the 1986 data removed from the data set. Statistical significance and interpretation did not change for grass or forb biomass, but the slope for total biomass under SLS no longer declined over years $(P>0.10)$. The $3 X$-IES slope still declined $(P<0.10)$. When the negative influence of the wildfire was removed, the biomass data supported the hypothesis that SLS and $2 X$-IES were equal and sustainable, but that $3 X$-IES was not.

The lack of response in vegetation composition and productivity on shortgrass prairie at 2X-IES contrasted with improvements on tallgrass prairie at 2 X-IES (Smith and Owensby 1978). Additionally, the changed composition and reduced productivity under 3X-IES contrasted with the minor and inconsequential changes on tallgrass prairie at $3 \mathrm{X}$-IES compared to $2 \mathrm{X}$-IES (Owensby et al. 1988). The difference in responses appears related to the importance of cool-season grasses as major forage-producing components of the plant community. Intensive-early grazing favors warm-season grasses because a sufficient portion of their growing season coincides with the late-season rest to allow replenishment (or perhaps improvement) of vigor. However, cool-season grasses are disfavored by IES because most, if not all, of their growing season occurs during the grazing season. Thus, they are at a competitive disadvantage with the warm-season grasses (Jameson 1991). This was evident in the reduction of western wheatgrass on shortgrass prairie and Kentucky bluegrass on tallgrass prairie (Smith and Owensby 1978). Improved composition and productivity were attained on tallgrass prairie where desirable forage grasses were all warm-season and undesirables were primarily coolseason, even when the stocking rate was increased (Owensby et al. 1988). However, because of the importance of retaining coolseason productivity on shortgrass prairie, IES will only maintain composition and productivity at an equal stocking rate to SLS
(2X-IES) and will cause deterioration at an increased stocking rate (3X-IES).

Biomass responses between July and October were not as expected. On tallgrass prairie, IES typically yielded less biomass than SLS in mid-July, but yielded biomass equal to (McCollum et al. 1990) or greater than (Smith and Owensby 1978) that produced by SLS by October. This suggests a grazing treatment $\times$ season interaction that did not occur in the present study. Instead, biomass declined under all treatments from July to October, even though IES was not stocked during this time period. Evidently, regrowth subsequent to steer removal was negligible, while biomass losses to senescence, decomposition, and insect or wildlife grazing continued to occur. This response provides further evidence of differential benefit from late-season rest between tallgrass and shortgrass prairie. We concur with Klipple (1964) that "lack of grazing after July, if it benefitted the vegetation at all, did not provide sufficient benefit to offset the adverse effects of accelerated stocking during the early part of the growing season."

\section{Management Implications}

These results imply that $3 \mathrm{X}$-IES should not be used on shortgrass prairie and possibly other range types where vigor and productivity of cool-season grasses is important. Double-stocked IES and SLS are essentially interchangeable, both in terms of vegetation and steer response. We concur with Bernardo and McCollum (1987) that IES still provides 2 positive alternatives when integrated into total ranch management. These are: (1) mixing IES and SLS on different land areas reduces market variability risk by allowing marketing twice per year and (2) IES allows periods of rest for integrating range improvements that require rest without reducing livestock numbers or overstocking other land areas.

\section{Literature Cited}

Bernardo, D.B., and F.T. McCollum. 1987. An economic analysis of intensive-early stocking. Oklahoma Agr. Exp. Sta. Res. Rep. P. 887.

Freund, R.J., and R.C. Littell. 1981. SAS for linear models. A guide to the ANOVA and GLM procedures. SAS Institute, Inc., Cary, N.C.

Jameson, D.A. 1991. Effects of single season and rotation harvesting on cool- and warm-season grasses of a mountain grassland. J. Range Manage. 44:327-329.

Klipple, G.E. 1964. Early- and late-season grazing versus season-long grazing of short-grass vegetation on the Central Great Plains. USDA Forest Serv. Res. Paper RM-II. 
Launchbaugh, J.L. 1957. The effect of stocking rate on cattle gains and on native shortgrass vegetation in west-central Kansas. Kansas Agr. Exp. Sta. Bull. 394.

Launchbaugh, J.L. 1967. Vegetation relationships associated with intensity of summer grazing on a clay upland range site in the Kansas 20- to 24-inch precipitation zone. Kansas Agr. Exp. Sta. Tech. Bull. 154.

Launchbaugh, J.L., and C.E. Owensby. 1978. Kansas rangelands, their management based on a half century of research. Kansas Agr. Exp. Sta. Bull. 622.

McCollum, F.T., R.L. Gillen, D.M. Engle, and G.W. Horn. 1990. Stocker cattle performance and vegetation response to intensive-early stocking of Cross Timbers rangeland. J. Range Manage, 43:99-103.
Owensby, C.E., R. Cochran, and E.F. Smith. 1988. Stocking rate effects on intensive-early stocked Flint Hills bluestem range. J. Range Manage. 41:483-487.

Smith, E.F., and C.E. Owensby. 1978. Intensive-early stocking and seasonlong stocking of Kansas Flint Hills range J. Range Manage. 31:14-17.

Vanzant, E.S., R.C. Cochran, K.A. Jacques, A.A. Beharka, T. DelCurto, and T.B. Avery. 1990. Influence of level of supplementation and type of grain in supplements on intake and utilization of harvested, earlygrowing-season, bluestem-range forage by beef steers. J. Anim. Sci. 68:1457-1468. 